\title{
ストロボ検 査
}

一粘膜の波を見る一

磯 貝豊

\section{Laryngostroboscopy}

\section{- Observation of the Travelling Wave of the Mucous Membrane-}

\section{Yutaka Isogai}

The purpose of laryngostroboscopy is to observe the vibration of the vocal fold. The essential principle of human vocal fold vibration during phonation is the travelling wave phenomenon of the mucous membrane. This wave crest travels from the lower portion to the upper-lateral portion of the vocal fold continuously. Consequenly, both the so-called upper lip and the lower lip indicate the wave crest of the travelling wave.

This travelling wave phenomenon was clearly observed by the newly developed digital subtraction X-ray stroboscopy.

Furthermore, easy visualization and quantitative analysis of vibrations of the vocal fold synchronously with some voice-ralated signals (VRS) including the voice signal, EGG, subglottic pressure on laryngostroboscopy has become possible by the newly developed laryngostrobography.

The observation of the travelling wave by conventional laryngostroboscopy was explained by the aforementioned method.

Key words：(1)喉頭ストロボスコピー, (2)デジタルサブトラクションX線ストロボスコピー, (3)喉頭スト ロボグラフィー, (4)声帯振動, (5)進行波

\section{1．喉頭ストロボスコピーの意義}

喉頭ストロボスコピーは，発声中の声帯の振動をスロー モーション像ないしは静止像として観察する方法である。

発声中の声帯は無関位発声でも約 $100 \mathrm{~Hz}$ から $300 \mathrm{~Hz}$ で振 動しているため, 通常光による観察では声帯振動の観察は 不可能である。しかし, 喉頭ストロボスコピーは, 発声中 の声帯の振動をスローモーション像で観察することができ るので，音声障害の原因を声帯振動の異常と関連づけて診 断することができ，さらには，声帯振動状態をモニターし ながら手術を行ったり，声带振動の改善度から術後の評価 をすることができるという意義がある。

言い換えれば，喉頭ストロボスコピーは，聴覚情報とし ての音声情報を視覚情報としての声帯振動情報に変換する 方法といえる（図 1).

\section{2. 喉頭ストロボスコピーの原理（図 2 ）}

声带の振動周波数（基本周期）は，音声の基本周波数 $\mathrm{F}_{0}$ （基本周期 $\mathrm{T}$ ）である.

したがって，声帯が定常的に振動しているときは，音声 の基本周波数 $\mathrm{F}_{0}$ （基本周期 $\mathrm{T}$ ）も一定である.

音声の基本周波数 $\mathrm{F}_{0}$ が一定の時，音声の基本周期（ $\mathrm{T} ）$
と同じ時間間隔で充分短い閃光 (ストロボ光)を発光させ ると，ストロボ光は常に一定の声帯振動位相で発光するこ とになるので，見かけ上，声帯振動はストロボ光が発光す る振動位相で静止しているかのように見える。これを静止 モードと仮称する。

そこで，音声の基本周期（ $\mathrm{T} ）$ より極くわずかの時間 $(\triangle t)$ だけ発光間隔を長くしてストロボ光を発光させる， すなわち, $(\mathrm{T}+\Delta \mathrm{t})$ の時間間隔でストロボ光を発光させ ると, ストロボ光が発光するタイミングは, 1 回発光する

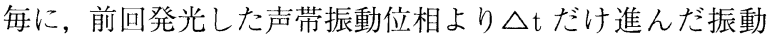
位相で発光することになるので，見かけ上，声帯振動は順

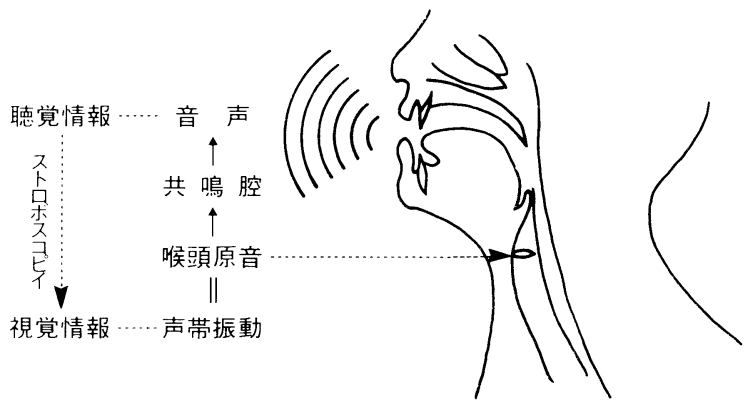

図 1 喉頭ストロボスコピーの意義 


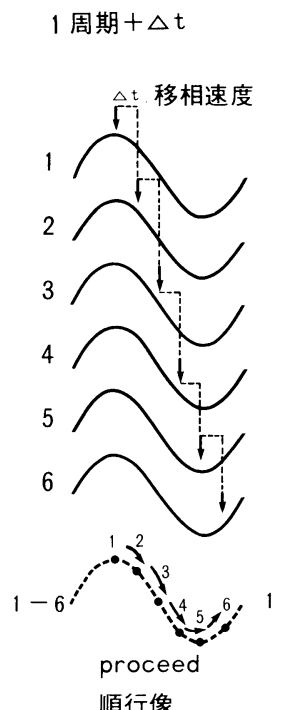

1 周期

1 周期 $-\Delta t$

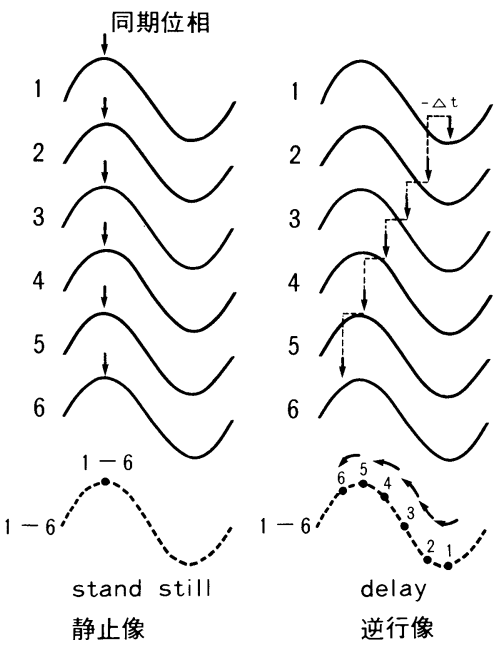

図 2 喉頭ストロボスコピーの原理

方向にゆっくり振動して見える。これを順行モードと仮称 する。

喉頭ストロボスコピーの順行モードで, 見かけ上 1 周期 声带が振動したように幻視されるのは, ストロボ光が最初 に発光した声带振動位相から再び最初に発光した振動位相 に戻った時点である。この見かけの 1 周期の間にストロボ 光が $\mathrm{n}$ 回発光したとすると, 見かけの振動周期は $\mathrm{n} \times(\mathrm{T}+$ $\triangle \mathrm{t})$ となる.

逆に, 音声の基本周期 $(\mathrm{T})$ より極くわずか（ $\triangle \mathrm{t}$ 時間） だけ発光間隔を短くしてストロボ光を発光させる, すなわ ち, $(\mathrm{T}-\triangle \mathrm{t})$ の時間間隔でストロボ光を発光させると, ストロボ光が発光するタイミングは, 1 回発光する毎に,

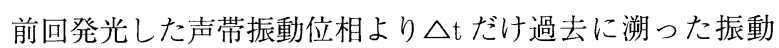
位相で発光することになるので, 見かけ上, 声带振動は逆 方向にゆっくり振動して見えることになる。この時の見か けの振動周期は, $\mathrm{n} \times(\mathrm{T}-\triangle \mathrm{t})$ となるが, これを逆行モー ドと仮称する。

喉頭ストロボスコピーの原理は, 音声の基本周期より $\triangle$ tだけずらした発光間隔で, 1 周期に 1 回だけストロボ光 を発光させることによって, 声帯振動を静止モード $(\triangle t=$ 0) で幻視したり, 順方向モード $(\triangle t>0)$ や逆行モード $(\Delta t<0)$ のスローモーション像として幻視することにあ る.

通常は順行モードで観察する.

喉頭ストロボスコピーによる見かけの声带振動周期は, $\Delta \mathrm{t}$ によって決定される。 $\triangle \mathrm{t}$ が小さくなる程見かけの声 帯振動はよりゆっくりした振動として幻視され， $\triangle \mathrm{t}$ が大 きくなるほど見かけの声帯振動はより速い振動として幻視 される、 $\Delta \mathrm{t}$ は, 声帯振動位相上の発光点をずらす時間と

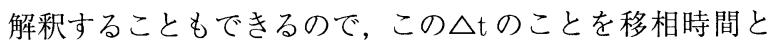
称することもある。

音声の基本周期を $\mathrm{T}$, 移相時間を $\Delta \mathrm{t},(\mathrm{T}+\Delta \mathrm{t})$ の発光
間隔でストロボ光が $\mathrm{n}$ 回発光したときの, 見かけの振動周 期を A とすると下の 2 式が成立する.

$$
\begin{aligned}
& \mathrm{A}=\mathrm{n}(\mathrm{T}+\Delta \mathrm{t}) \cdots \cdots \cdots(1) \\
& \mathrm{T}=\mathrm{n} \times \Delta \mathrm{t} \cdots \cdots \cdots(2)
\end{aligned}
$$

(2)の $\Delta t$ を(1)に代入すると，

$$
\begin{aligned}
\mathrm{A} & =\mathrm{n}(\mathrm{T}+\mathrm{T} / \mathrm{n}) \\
& =\mathrm{n} \times \mathrm{T}+\mathrm{T} \\
\therefore \mathrm{n} & =(\mathrm{A}-\mathrm{T}) / \mathrm{T} \\
& =\mathrm{A} / \mathrm{T}-1 \cdots \cdots \cdots(3)
\end{aligned}
$$

$\mathrm{A}$ を周波数 $\mathrm{A}_{0}$ であらわすと,

$$
\mathrm{A}=1000 / \mathrm{A}_{0}
$$

$\mathrm{T}$ を基本周波数 $\mathrm{F}_{0}$ であらわすと,

$$
\mathrm{T}=1000 / \mathrm{F}_{0}
$$

$\therefore \mathrm{n}=\mathrm{F}_{0} / \mathrm{A}_{0}-1$

見かけの周波数 $\mathrm{A}_{0}$ を $1 \mathrm{~Hz}$ にすると,

$$
\begin{aligned}
\mathrm{n} & =\mathrm{F}_{0}-1 \\
& \fallingdotseq \mathrm{F}_{0} \ldots \ldots . . .(4)
\end{aligned}
$$

したがって, ストロボの発光回数が $\mathrm{F}_{0}$ 回になるように $\triangle \mathrm{t}$ を設定すると, 見かけの周波数 $\mathrm{A}_{0}$ が $1 \mathrm{~Hz}$ になる.

(4)式を(2)式に代入すると,

$$
\Delta \mathrm{t}=\mathrm{T} / \mathrm{n} \fallingdotseq \mathrm{T} / \mathrm{F}_{0}
$$

となる.

たとえば，基本周波数 $\mathrm{F}_{0}=100 \mathrm{~Hz}$ の原振動を，見かけ の振動周波数 $\mathrm{A}_{0}=1 \mathrm{~Hz}$ の振動として見える様にするには $\Delta \mathrm{t} \fallingdotseq \mathrm{T} / \mathrm{F}_{0}=10 \mathrm{~ms} / 100=0.1 \mathrm{~ms}$ にすればよい.

喉頭ストロボスコピーでは, 声帯振動が定常的で, 音声 の基本周波数（ $\mathrm{F}_{0} ）$ あるいは基本周期 $(\mathrm{T})$ が一定の時に のみ, 見かけの声带振動像も定常振動として幻視される.

逆にいうと, 喉頭ストロボスコピーで声帯振動が定常振 動として幻視されるときは, そのストロボ像は原振動を直 接反映しているとみなしてよい.

しかし, 声帯振動が乱れて, 非定常的な振動に見えると きは, そのストロボ像は, 原振動の乱れを直接反映したも のでは無い.

\section{3. 喉頭ストロボスコープの使用上の注意}

喉頭ストロボスコープ（図 3 ）は, 発声中の音声の基本 周波数 $\mathrm{F}_{0}$ (あるいは基本周期 $\mathrm{T}$ ）を抽出して発声中の 声带振動像をスローモーション像として幻視する装置で ある1).

したがって，喉頭ストロボスコープの使用に際して最も 大切な点は, 音声の基本周波数 $\mathrm{F}_{0}$ あるいは基本周期 $\mathrm{T}$ を 正確に抽出することである.

音声の基本周波数 $\mathrm{F}_{0}$ あるいは基本周期 $\mathrm{T}$ は, 通常, コ ンタクトマイクロフォンを介して電気的に抽出する機構に 


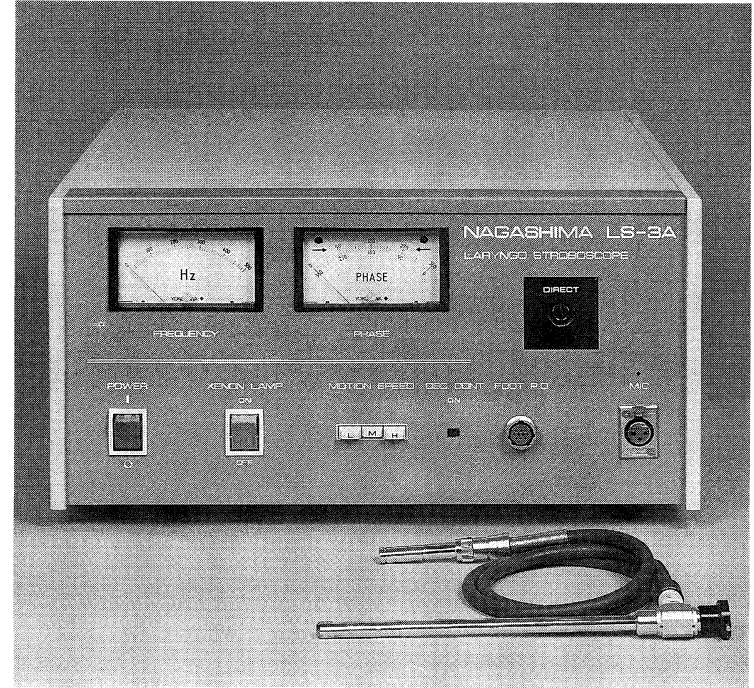

図 3 喉頭ストロボスコープ（永島製 LS-3A）

なっている.

この方式だと, 音声が身体組織を通じて伝達される間 に音声信号中の高調波成分が自然に減衰することと, 周囲 の環境雑音が混入しないことによって, 音声の基本周波 数 $\mathrm{F}_{0}$ あるいは基本周期 $\mathrm{T}$ 電気的に抽出するのが容易に なるからである。

コンタクトマイクロフォンを接触させる部位は, 音源の 近く，すなわち，喉頭近傍が良いが，甲状軟骨にあまり近 すぎても良くないことがある。

コンタクトマイクロフォンは, コンタクト部分の全面を 均等に軽く押し当てるくらいの感じで頸部に当てることが 大切である。一部分しか接触していなかったり, 浮いてし まったりしている場合には，音声の基本周波数 $\mathrm{F}_{0}$ を正確 に抽出できないので，喉頭ストロボスコピーで非定常振動 に見えてしまうことになる。

それゆえ，コンタクトマイクロフォンを適正な条件で頸 部にあてさせるということが, 喉頭ストロボスコピーを行 う上での最大の注意点である.

コンタクトマイクロフォンが適正にあたっているかどう かは，コンタクトマイクロフォンを接触させて発声させた 時に, 喉頭ストロボスコープの機器上に表示される音声の 基本周波数 $\mathrm{F}_{0}$ が一定になっているかどうかでチェックす ることができる．また，静止モードで見たときに，声帯振 動が静止して見えるかどうかでもチェックすることができ る.

\section{4. 声帯振動概念}

4-(1) 開閉運動としての概念（図 4)

正常な声帯振動は，声帯上面からの観察では，左右対称 な開閉運動として観察される ${ }^{2)}$ (図 4$)$.

声門が開いて行く位相を開大期 (opening phase), 閉 じて行く位相を閉小期 (closing phase), 開大期から閉小
期に移行する境の位相を最大開大期 (opened phase)，声 門が閉じている位相を閉鎖期（closed phase）という.

声門が開いている位相，すなわち，開大期と閉小期を合 わせた位相を開放期 (open phase) といい，声帯振動 1 周期中の開放期の割合を開放時間率 (open quatient, OQ) で表す。

声帯の最内側の縁を声帯縁（free edge）といい, 開大 期における声帯縁のことを上唇 (upper lip)，閉小期にお ける声帯縁のことを下唇（lower lip）という.

また，閉小期には，声帯上面を外方に向かって移動する 波が見られる。この波の移動現象のことを狭義の粘膜波動 (mucosal wave) という.

4-(2) 進行波（travelling wave）としての概念（図 5(A), (B))

前頭面からのX線ストロボスコピー3,4)による声帯振動 の解析によって, 声帯振動の本質は, 声帯内側下面から上 面外側に向かって連続的に移動する粘膜隆起を波頭とする 進行波 (travelling wave) 現象であることが解明されて いる.

図 5-(A)は, 犬摘出喉頭の声带粘膜上皮下に微小な鉛 マーカーを刺入して声帯振動時のマーカーの振動軌跡を前 頭面から解析 ${ }^{3)}$ したもので, 声带遊離縁のマーカーの振動 軌跡 (点線) を元に, 1 周期中の声帯振動の輪郭（実線） を描いたものである。

図 5 -(B) は, 人発声時の前頭面の声帯振動像を解析 ${ }^{4)}$ するために， 1 周期間中の全画像を加算平均した像をマス ク像として, 各振動位相の画像からマスク像をデジタルサ ブトラクションしたもので, 黑色矢印の先に示されている 黑色部分が実際の振動領域である。この黒色部分は, 進行 波の波頭（移動する粘膜隆起）に相当する.

波頭は，1 から 4 の閉鎖期間中に，両側接触したまま， 形態を扁平化させつつ上方に移動し，5の開大期の始まり から 6 の最大開大期まで外方に向かって開離し，7 から 8 の閉小期で引き続き外方に移動する部分（下向き矢印）と 内下方に突出する部分（横向き矢印）とに分裂する様がはっ きりわかる。

すなわち，進行波は，閉鎖期から開大期にかけて声帯内 側下面から上面に向かって移動し，閉小期に入ると，引き 続き連続して外側に向かう波と, 逆方向の内側下面に向か う波とに分裂する。

声帯上面からの観察で，閉鎖期から最大開大期にかけて 声帯縁を形成する「上唇」は，声帯内側下面から上面外側 に向かって移動する進行波の波頭（粘膜隆起）であり，閉 小期にこの波頭が引き続き減衰しながら外方に向かって移 動する現象が「狭義の粘膜波動」である。閉小期に声帯縁 を形成する「下唇」は，この粘膜波動と逆方向の内下方に 向かう分裂した波頭である。

すなわち, 声帯振動を上面から観察したときの声带縁と しての「上唇」「下唇」は，声帯の特定（固定）の部位を 指すのでは無く，移動する粘膜隆起を波頭とする進行波の， 

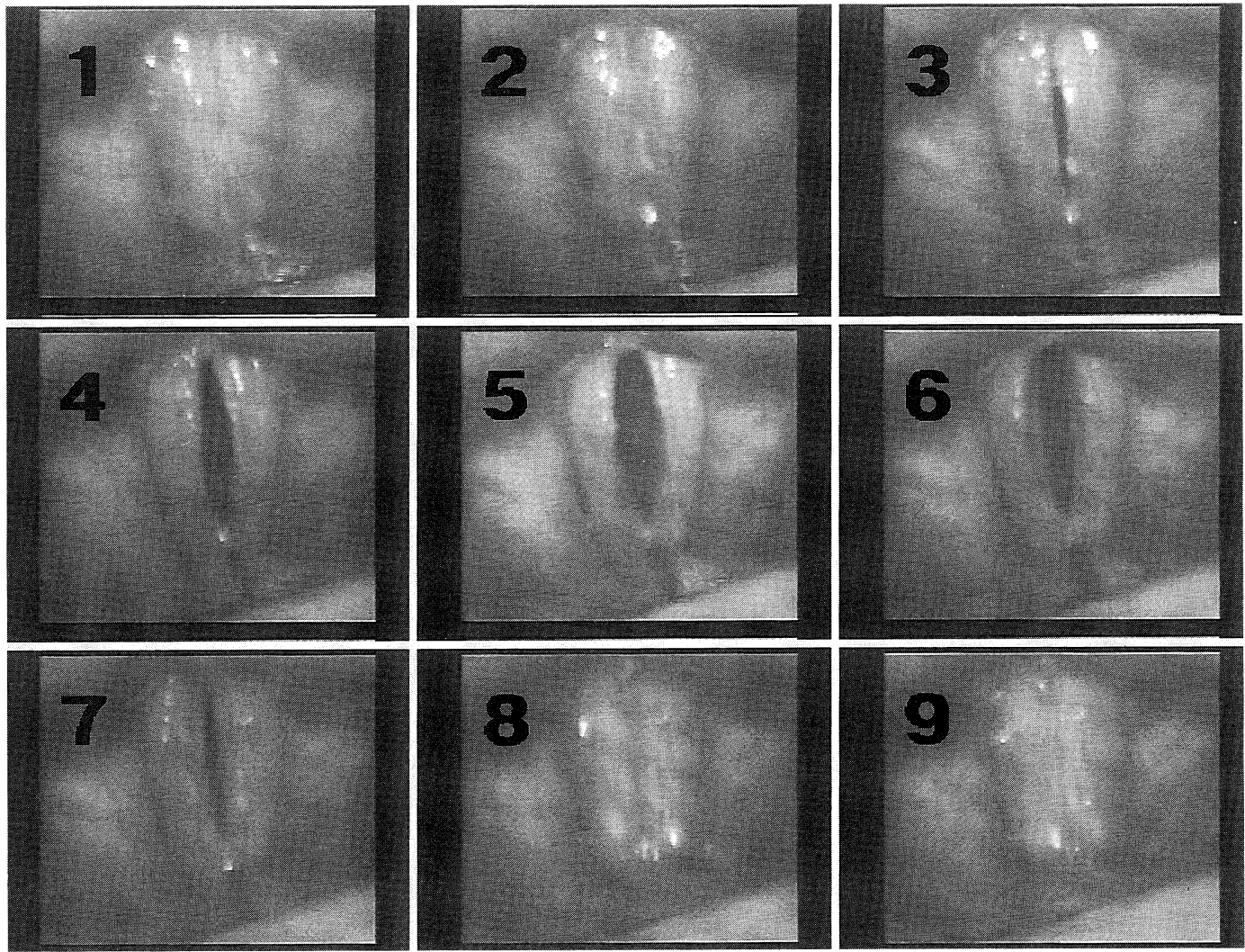

図 4 声帯上面から記録した声帯振動の 1 周期. $1 \rightarrow 2 ：$ 閉鎖期， $3 \rightarrow 4 ：$ 開大期， $5 ：$ 最大開大期， $6 \rightarrow 7$ : 閉小期, $8 \rightarrow 9$ : 閉鎖期

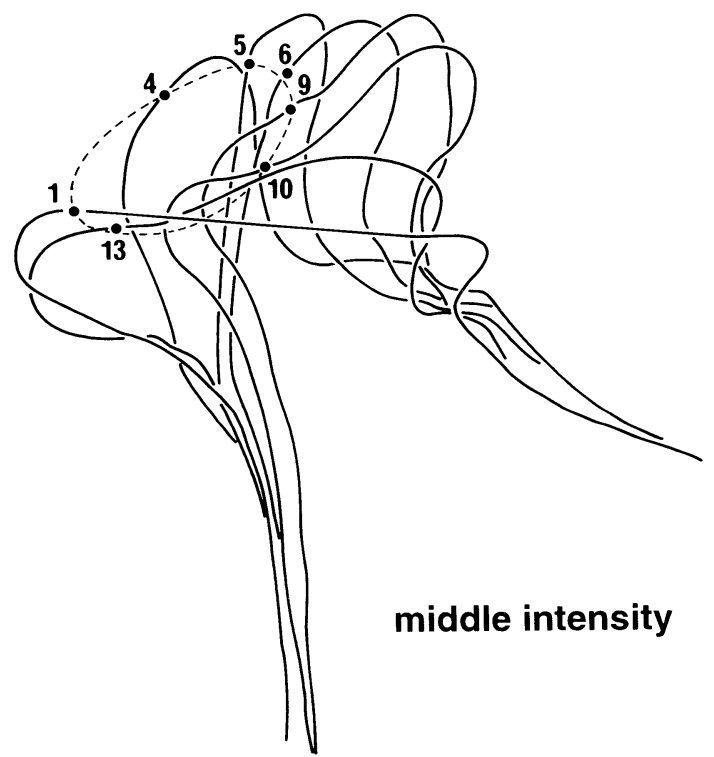

図 5-(A) 前頭面X線ストロボスコピーの解析結果. 声帯縁 に刺入した鉛マーカーの振動軌跡（点線）を元に, 声帯振動像の輪郭の変化を描いたもの（犬摘出喉 頭).
進行方向を逆にしたふたつ波頭のことを意味する。また 「狭義の粘膜波動」は, 閉鎖期から開大期にかけて声带縁 を形成する波頭としての「上唇」が, 閉小期にそのまま外 側に移動する現象を意味する。

最近では，「進行波現象全体」を「粘膜波動」と称する ようになってきている。

声帯振動の本質は, 声帯内側下面から上面外側に向かっ て連続的に移動する粘膜隆起を波頭とする進行波である.

声帯筋層は, この進行波の発生条件を規定する土台とし ての役割を果たしている ${ }^{5,6)}$.

4 -(3) Shanhärl の声帯振動模式図（図 6)

上面から観察した声帯振動様式を元に, Shanhär1 ${ }^{7)}$ が 描いた, 前頭面の声帯振動想像図 (図6)は, X 線ストロ ボスコピーによる前頭面振動様式とよく似ている。 Shanhärl は, 声带振動を進行波 (travelling wave) という概 念で捉えることこそできなかったが, 進行波の概念で見直 してみても，とてもわかりやすい図である.

\section{5. 喉頭ストロボグラフィーによる声帯振動の解析}

\section{5 - (1) 喉頭ストロボグラフィー}

喉頭ストロボスコピーは, 声帯振動を見かけのスローモー ション像として幻視する方法であるが, 喉頭ストロボグラ フィー8, 9) は, 声帯振動画像だけでなく, 声帯振動に同期 した音声関連信号（音声信号・EGG・声門下压）も声帯 

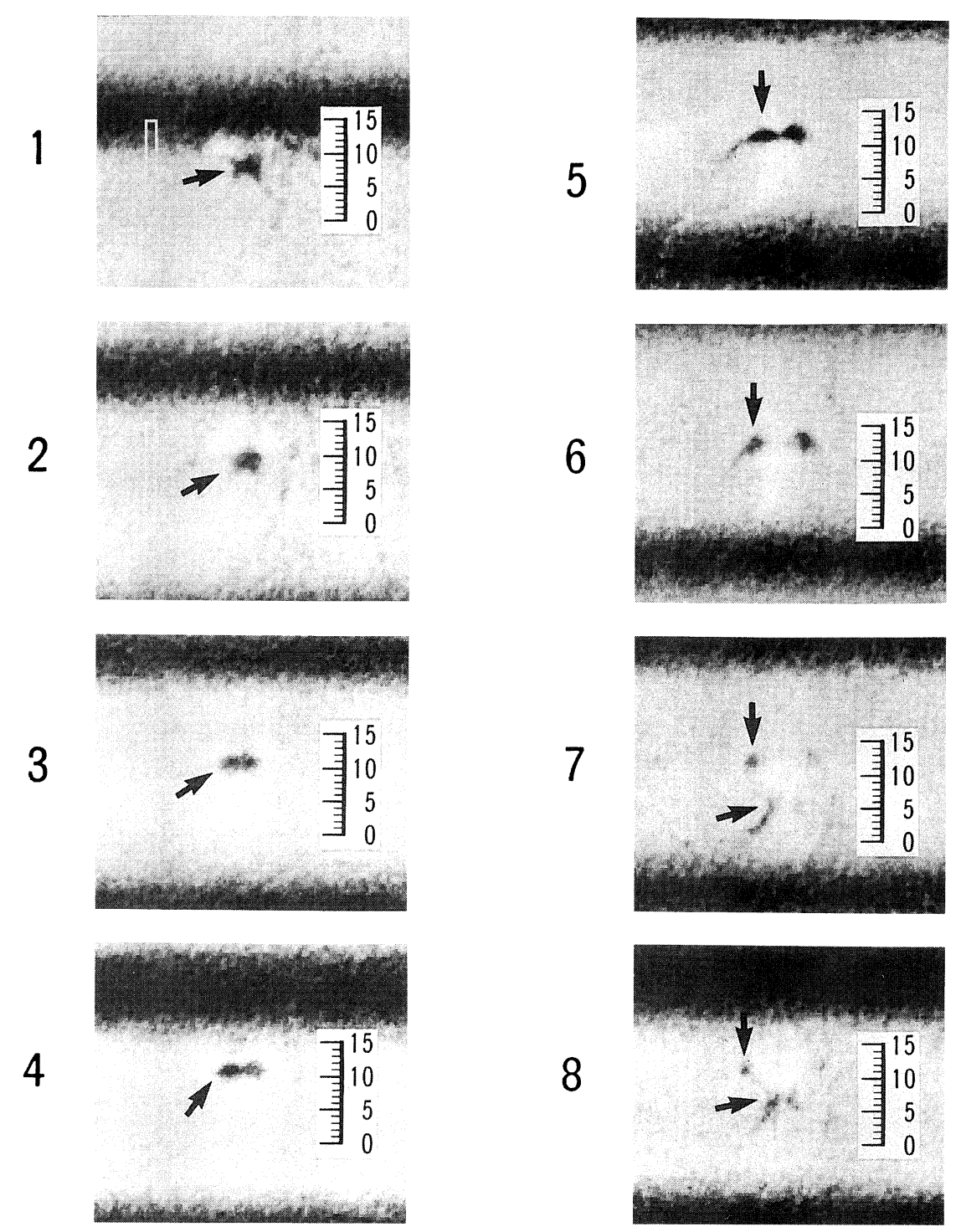

図 5一B デジタルサブトラクションX線ストロボスコピーによる,人発声時の前頭面 $\mathrm{X}$ 線ストロボスコピーの解析結果. 黑色矢印の先の黑色部分が進行波の波頭 （粘膜隆起）に相当する部分.

振動画像と同時にストロボ処理（ストロボスコピー化）す ることによって, 声帯振動画像と音声関連信号との関係を 定量的に解析する方法である.

$$
\text { 5-(2) ストロボモーションアナライザー（図７） }
$$

喉頭ストロボグラフィーを日常臨床で簡易に行えるよう， ストロボモーションアナライザーを(株) フローベルなら びに（株）永島医科器械と共同開発した。

喉頭ストロボスコープは永島製 LS-3A を用い，音声の 基本周波数が変わっても, 見かけのスピード（移相速度） を一定にできるよう改良した。

図 7 は, システムのブロック図である.

内視鏡に接続した CCD カメラからの声帯振動画像を, 1 フレーム分ずつビデオメモリーに書き込みながら，128 フィールド分の RGB 画像メモリーにリアルタイムで連続
的に取り込む．同時に，喉頭ストロボスコープの発光信号 に同期した位相の音声関連信号（音声信号・EGG 信号 · 声門下圧信号）を A/D コンバーターを介してオーバーレ イメモリーに取り込む。この両者を, スーパーインポーザー を介して合成映像出力する.

VTRに録画した合成映像も, VTR 再生時に再びスト ロボモーションアナライザーに取り込むことによって，任 意の振動周期をストロボグラフィー化することができる.

また, 声帯振動様式と, 声帯振動位相と音声関連信号位 相との位相関係の両者を, 声帯振動周期全長にわたって 1 枚の画像上で定量的に解析できるよう, 声带前後軸に直交 する任意の位置の振動解析部分を解析対象として指定し, 同じ位相の音声関連信号と合成して継時的に連結すること によって, 128フィールド分の振動周期を 1 枚の画像とし 

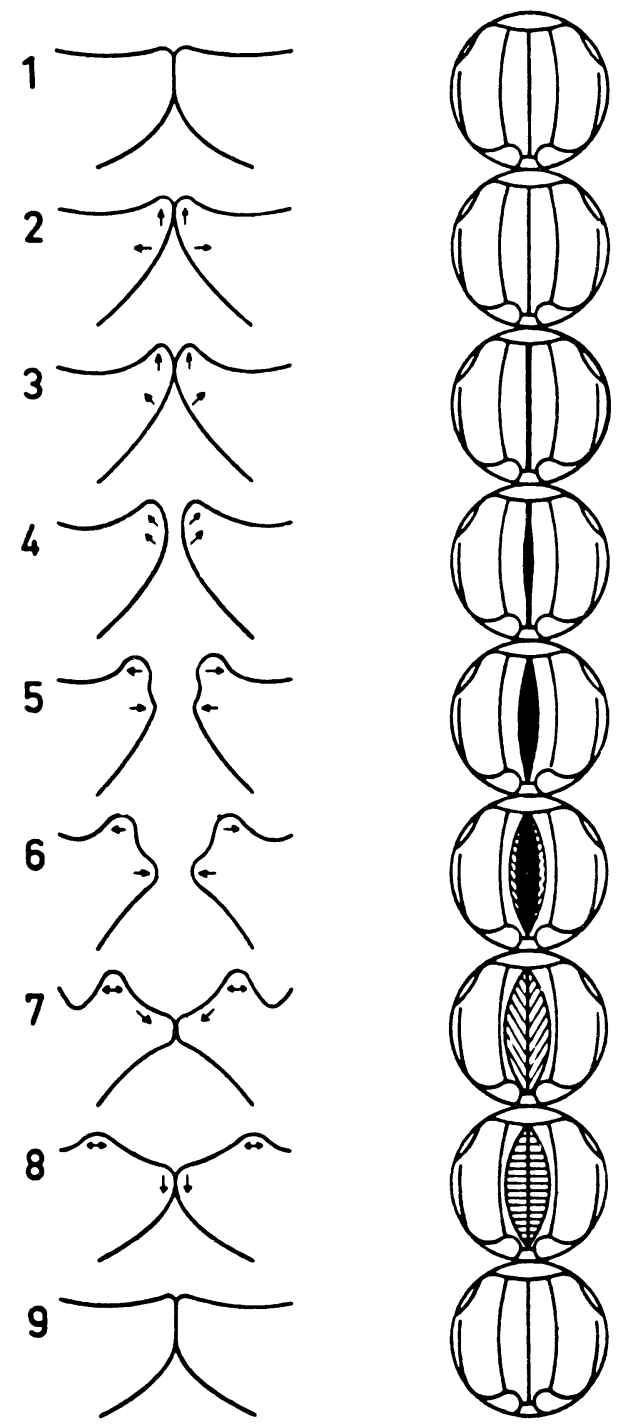

図 6 Shanhärl の声带振動模式図

CONT.MIC. LARYNX ENDOSCOPE

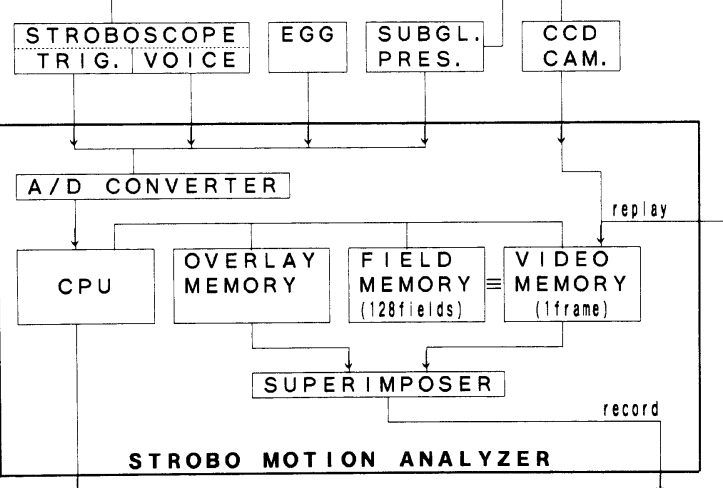

COMPUTER DISPLAY VIDEO MON ITOR $\equiv$ VTR

図７ストロボモーションアナライザーのシステム図

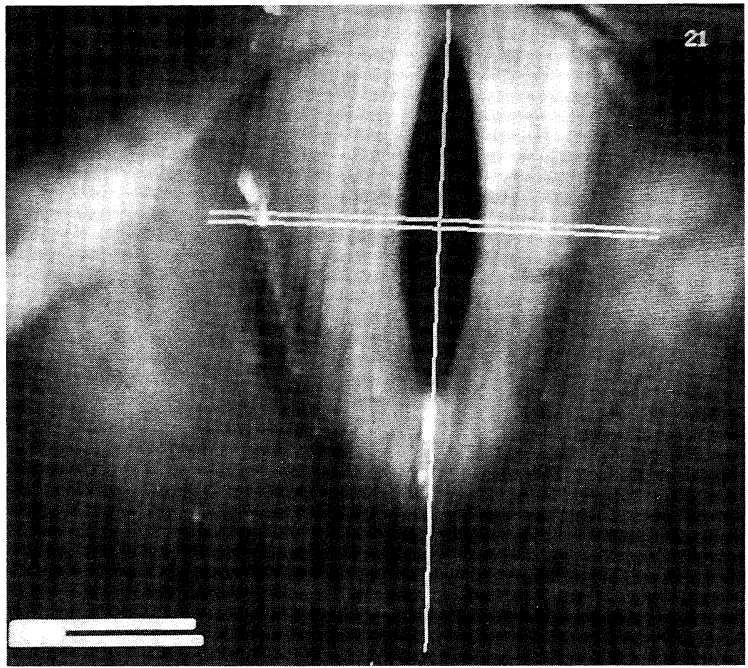

図 8 声帯振動解析区間の設定

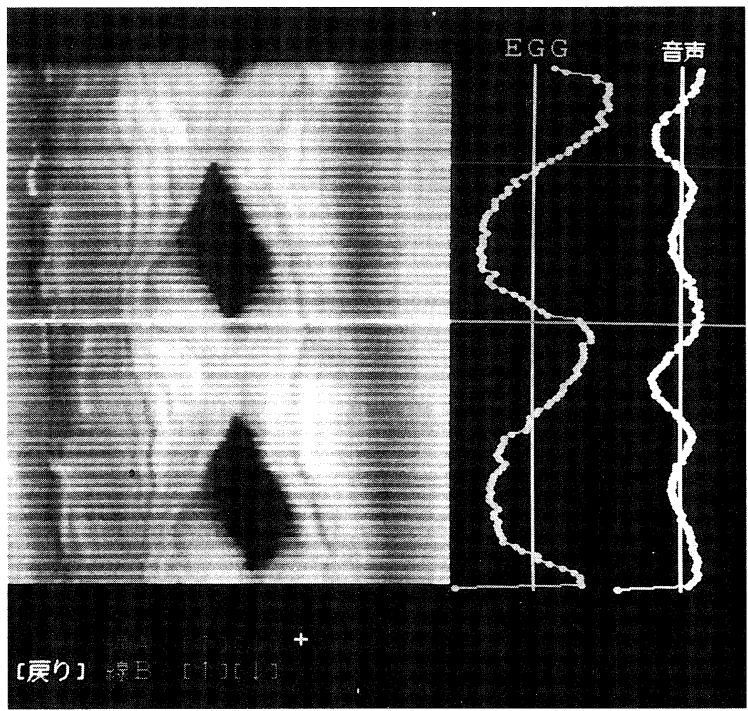

図 9 無関位発声のストロボグラム

て表示できるようにした。これをストロボグラムと呼ぶ.

図 8 の声带前後軸に直行した 2 重線が解析対象区間であ る.

図 9 は, 図 8 で指定した声帯振動画像の解析区間だけを 128フィールド分だけ継時的に連結した画像を左欄に，こ れに同期した位相に扮ける EGG 信号を中央に，音声信号 を右闌にスーパーインポーズしたストロボグラムである.

発声条件は無関位発声である。

CLOSED PHASE から OPENING PHASEにかけて 上唇が外方に開大し, CLOSING PHASEからは下唇が内 方に閉鎖し，CLOSED PHASEで下唇から両側声帯が接 触し, CLOSED PHASEを経て再び OPENING PHASE にいたる 2 周期分の振動様式が 1 枚の画像で一目瞭然にわ かる。

この上唇, 下唇は, 特定（固定）の部位の振動ではなく, 


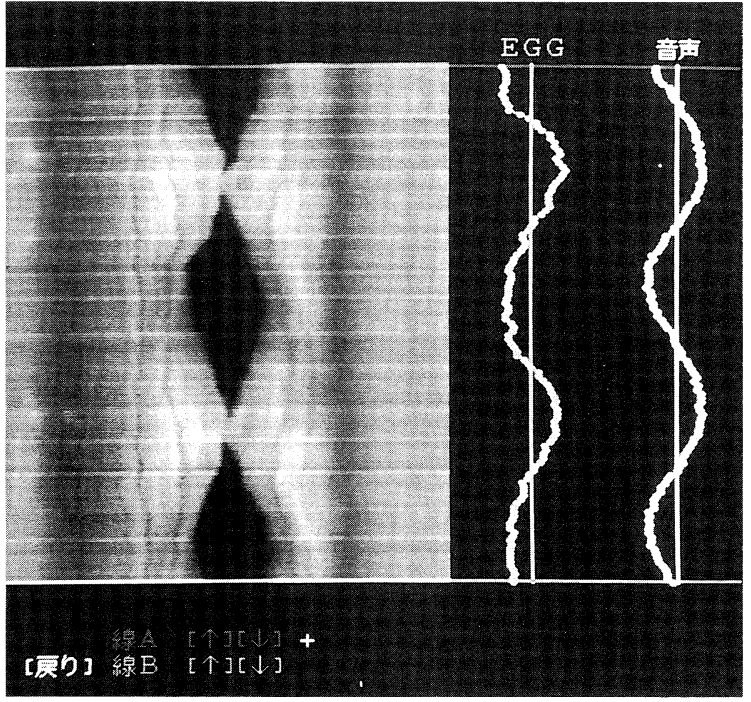

図10＼cjkstart高音発声のストロボグラム

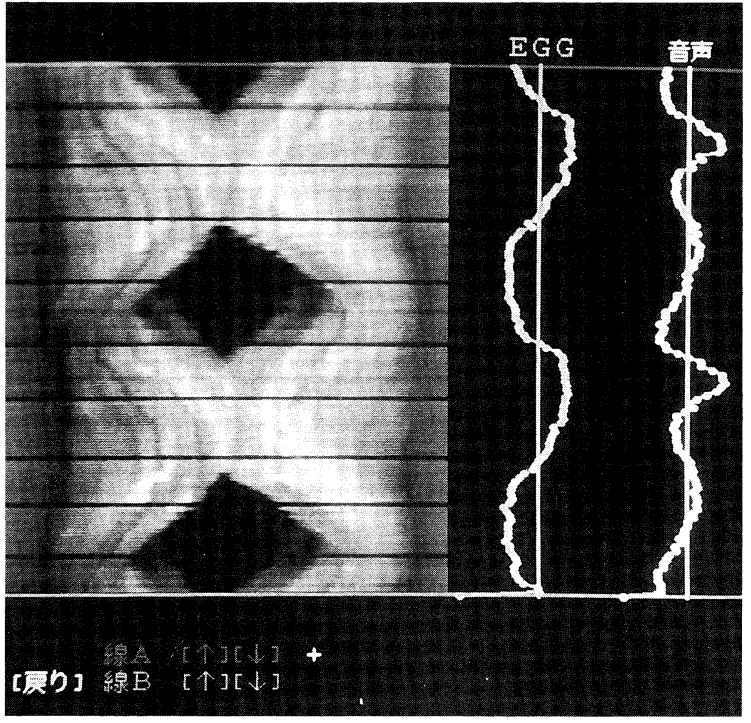

図11 低音発声のストロボグラム

移動する粘膜隆起を波頭とする TRAVELLING WAVE （進行波）の波頭であり，上唇は CLOSED PHASEから OPENING PHASE にかけて内下方から上外方へ向かう 粘膜隆起の波頭を，下唇は CLOSING PHASE 時の内下 方へ向かう波頭を指す。

また，声带上面の血管群の水平方向の振動様式が，まる で地図上の等高線のようにはっきり見える。声帯上面の血 管の水平方向の移動距離は, 最内側の血管が最大で, 外側 に向かうほどその移動距離が小さくなっており，最内側の 血管と最外側の血管との距離は CLOSED PHASEの最後 の位相で最大となり，CLOSING PHASEの途中で最小と なっている。

画面中央欄の EGG 信号が右端になる位相は CLOSED PHASEの始まりの位相に一致しており，CLOSED PHASE

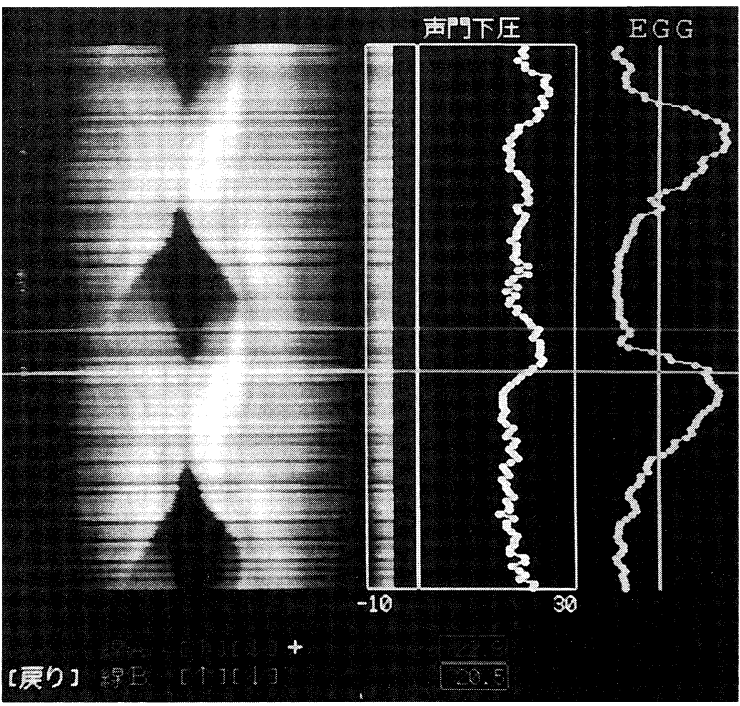

図12 声門下圧と EGG のストロボグラム

の最後, OPENING PHASEの起始の位相では, 未だ両 端の中央部あたりにあるが，OPENED PHASE で左端位 相になる。

図10は同一被験者の高音発声におけるストロボグラム， 図11は低音発声におけるストロボグラムである，振動振幅 が変化しているが, 振動パターンと位相関係は変わらない ことがわかる。

図12は声門下圧 (中央闌) と $\mathrm{EGG}$ (右欄) とを同時に 記録したストロボグラムである。

声門下圧が最大になる位相は, CLOSING PHASE 途中 から CLOSED PHASEの起始位相の間であり，声門下圧 の最大位相の最後期と EGG の最右端位相とが略一致して いる.

\section{6. 代表的疾患の喉頭ストロボスコピー像}

喉頭ストロボスコピーでは, 声带の振動位相と振幅，粘 膜波動（進行波の波頭の移動）が左右声帯で対称かどうか, 前後軸上で均一かどうかを中心に，声帯振動を観察する.

声带ポリープやポリープ様声帯など，粘膜の硬化が無い 柔らかい腫瘤性病変では, 腫瘤の乫出や重さによる影響が 見られるが，進行波の移動は障害されない.

しかし, 癌, 囊胞, 㓔痕などの粘膜硬化病変では, 病変 部位の硬化によって, 当該部位で進行波の進行がストップ する現象が見られる. 声帯溝症でも, 硬化した溝が形成さ れている部位での進行波の途切れが観察される.

声帯白板症では, 病変が薄く硬化度が小さければ進行波 は障害されないが, 厚くなって硬化度が増すと, それに比 例して進行波が障害される。進行波が障害されているとき は, 癌化していることが多い.しかし, 進行波が障害され ていないからといって，癌化を否定することはできないの で，バイオプシーによる組織検查は必須である。

反回神経麻痺では, 左右声帯の位置と筋緊張の違いによ 
る左右の振動の差が見られる.

また, 声帯の病変に加えて, 粘調度の高い粘液が病変部 に絡まることによって, 声帯振動がさらに悪影響を受ける こともあるので, 粘液の振動状態も観察する必要がある. もっとも大切なことは, 声の高さ, 強さなどの発声条件 を変えて発声させたときの声带振動の変化をみることであ る.

特に, 声帯結節などの微小な病変は, 高音で発声させな いと, 声帯振動への悪影響がわからないことが多い.

一般的に, 声帯縁の病変では低音発声は障害されず, 高 音発声が障害される. 声門下病変では, 声帯縁の病変と逆 に, 低音発声が障害されるが高音発声は障害されない.

その理由は，低音発声の方が進行波の波頭が大きく，か つ, 進行波の起始部が高音発声よりも声門下方にあるから である。

\section{7. 今後の展望}

喉頭ストロボスコピーは, 声帯振動の動態を観察するも のなので, VTRに記録することによって, 声帯振動動態 を繰り返し再生できる。

今後は, コンピュータによるデジタル画像処理技術の発 展によって, 喉頭ストロボグラフィーのような定量的な解 析を,より高度により簡単により安価に行えるようになる ことが期待される。

本論文の要旨は, 第 8 回日本喉頭科学会における教育パ ネル「実際に役に立つ喉頭疾患の検査法」において報告し た。

なお，第39回日本気管食道科学会の研修会において報告
した「喉頭ストロボスコピーによる声帯振動の観察」と重 複する部分が多いことをお断わりする.

\section{参 考 文 献}

1) 磯貝 豊: ストロボスコピー一器械の使い方と臨床 的意義. 耳鼻と臨床 $31: 859 \sim 862,1985$.

2）平野 実：声帯の振動状態に関する検查. 声の検査 法 (第 1 版), (日本音声言語医学会編) 79 87, 医歯 薬出版株式会社, 東京, 1979 .

3）磯貝 豊：X線ストロボスコピーによる声带振動の 解析. 耳鼻 $27: 883 \sim 930,1981$.

4）磯貝 豊：デジタルサブトラクションX線ストロボ スコピーによる声带振動の解析. 喉頭 6:140 146, 1995.

5）平野 実：振動体としての声帯の構造. 日耳鼻 77 ： 1341 1349, 1973.

6）都築 達: 声帯層構造を考慮した声帯振動の基礎的 研究. 耳鼻 $30: 131 \sim 152,1984$.

7) Shanhärl E: Die Stroboskopie in der praktischen Laryngologie, Georg Thieme Verlag, Stuttgart, 1960.

8）磯貝 豊: STROBOGRAPHYによる喉頭の機能検 查. 喉頭 $6: 91 \sim 96,1995$.

9）磯具 豊：喉頭ストロボグラフィーによる声帯振動 の解析一解析機能の改良一. 喉頭 $8: 27 \sim 32,1996$.

別刷請求先 $\bar{\top} 160$ 東京都新宿区信濃町 9 番地 2 東京電力病院耳鼻咽喉科 磯貝 豊 